\title{
Polarization and Conflict: Theoretical and Empirical Issues*
}

\author{
JOAN ESTEBAN \\ Institut d'Anàlisi Económica, CSIC, Barcelona
}

GERALD SCHNEIDER

Department of Politics and Management, University of Konstanz

\begin{abstract}
Recent formal and statistical research in political science and economics strongly indicates that various forms of political and social polarization increase the risk of violent conflict within and between nation states. The articles collected for this issue explore this crucial relationship and provide answers to a variety of topics: First, contributors address how institutions and other contingent factors mediate the conflict potential in polarized societies. Second, this special issue compares the explanatory power of income polarization with traditional and new measures of inequality. Third, the contributions examine how groups form and coalitions are built in polarized societies and how this affects political decisionmaking. Finally, the special issue analyses the interconnections between interstate war, internationalized conflict and polarization. This introduction synthesizes the literatures that have been developed on the issue of polarization and conflict in the various social scientific disciplines. The authors particularly discuss the similarities between economic models of conflict and the so-called crisis bargaining literature which has been mainly developed within political science. The article shows the differences between 'polarization' and 'inequality' and introduces the various measures of diversity that have been used in the study of interstate and intrastate conflict during the past few decades.
\end{abstract}

\section{Introduction}

Recent developments around the world have shown that ideological, economic or religious polarization between contending groups is a major source of conflict and, hence, one of the key impediments to social and political progress. Commenting on the political prospects of Pakistan's President Musharraf, The Times (2007) wrote: 'polarisation has already made Pakistan all but ungovernable'.

\footnotetext{
${ }^{*}$ This article is part of the Polarization and Conflict Project CIT-2-CT-2004-506084 funded by the European Commission-DG Research Sixth Framework Programme. This article reflects only the authors' views and the Community is not liable for any use that may be
}

New York Times columnist Brooks (2004) heralded, in a completely different context, before the 2004 presidential elections in the United States, a new era of 'political segregation' and wrote: 'People lose touch with others in opposing, now distant, camps. And millions of kids are raised in what amount to political ghettoes.' The contested presidential elections in Ukraine instigated, half a year later, the fear of 'further splits and the polarisation of the country', as the BBC observed

made of the information contained therein. We would like to thank Nils Petter Gleditsch, Frank Wayman, and the contributors to the special issue for their assistance. Correspondence: Joan.Esteban@iae.csic.es, Gerald.Schneider@uni-konstanz.de. 
(Lukov, 2004), and the diplomatic correspondent of The Guardian warned, two years after the attack on the World Trade Center, that the Al-Qaeda terrorist network had already reached one of its main goals: 'the one-sided nature of the conflict [between Israel and the Palestinians] and the emotions it arouses beyond its boundaries have helped Bin Laden achieve the fourth and most important of his objectives: polarisation' (MacAskill, 2003).

The process of increasing social and political polarization seems to go hand in hand with economic polarization. In the presentation of the 1996 World Bank Human Development Report, James Gustave Speth (1996) expressed the view that 'Unfortunately, we live in a world that has in fact become more polarized economically, both between countries and within them. If current trends continue, if they are not quickly corrected, economic disparities will move from inequitable to inhuman - from unacceptable to intolerable.'

According to a recent definition, polarization results from the interaction of withingroup identity and across-group alienation (Esteban \& Ray, 1994). While the group members show identification with each other in a polarized society, they feel socially or ideologically separated from the members of other groups. Esteban \& Ray (1999) show that the level of conflict increases with the magnitude of polarization. If there are two groups, the intensity of conflict is most pronounced, with a bimodal distribution of the population over opposing goals.

As is well known, this conjecture has a distinguished history. Marx (1931 [1867]) and De Tocqueville (1857) contended that a revolution or, alternatively, a breakdown of the ancien régime becomes more likely if the workers start to organize themselves politically and if their economic situation does not improve in line with the welfare of capitalists. Ample illustrative evidence seems to support this hypothesis. The polarization between contending social forces is seen as a key cause of the end of the Weimar republic (Bracher, 1955; Winkler, 1994), the Russian revolution (Rosenberg \& Koenker, 1987), and many other decisive breakdowns of political order (Linz, 1978).

Interestingly, modern conflict research has only recently started to pay attention to the effects of a growing ideological, social or economic distance between contending social forces. One reason for the hesitation to employ polarization as an explanation of conflict might be the disrespute that the related concept of alienation has gained during the communist era. A further hindrance is that the track record of variables that are most closely related to polarization - fractionalization and inequality - as predictors of violent conflict is rather mixed. Lichbach (1989) showed in an early survey article that the empirical studies on the relationship between inequality and conflict have come up with only inconclusive results. However, recent empirical work (Montalvo \& Reynal-Querol, 2005) and Reynal-Querol (2002) provides evidence suggesting that polarization outperforms fractionalization as a predictor of civil conflict.

In any case, there seems to be agreement that groups rather than individuals are the decisive actors in large-scale violent conflicts. Recent formal and empirical contributions to the literature on armed violence have converged considerably and put groups at the centre stage of their analyses. However, the contributions diverge sharply with regard to the role that these very groups play. One line emphasizes diversity and social fragmentation into groups and uses indices of fractionalization as an indicator for social unrest and civil war. The second approach considers that the existence of few and large-sized groups with opposing interests is more conducive to conflict than many, smaller-sized groups. The polarization in the distribution of the 
population is the key variable for this approach. Which of the two scenarios is more likely to ignite conflict is a theoretical and empirical open question that this special issue seeks - together with some related ambitions - to answer.

Accordingly, we try to settle some of the disputes that have occurred over the role that various forms of diversity play in conflict, both at the international and the domestic level. To this end, this introduction discusses the extant literature that analyzes the impact of polarization on the likelihood of civil and interstate war. We finish by summarizing the key insights of the articles that have been contributed to this special issue around three sets of questions: (1) What is the relationship between polarization and conflict under alternative institutions? (2) How do groups form in polarized societies and how does coalition-building under the shadow of diversity affect political decisionmaking? (3) How do interstate and internationalized conflict and polarization hang together?

\section{Measuring Social Cleavages: Fractionalization vs. Polarization}

Polarization is one of those ideas of which most social scientists believe they have an implicit understanding. However, as is often the case, the overhasty acceptance of the seemingly obvious has contributed to a considerable carelessness in the application of this concept. In recently published work, polarization is equated with, for instance, income inequality (Keefer \& Knack, 2002), the range of political positions taken by party supporters (Layman \& Carsey, 2002), the electoral strength of post-communist parties in transition countries (Frye, 2002), and highly aggregated index measures including information on income, ethno-linguistic fractionalization and institutional quality (Woo, 2005). Given the overstretch of 'polarization' as a social scientific concept, it seems mandatory to define clearly what we understand here by this notion.

Starting with the works of Esteban \& Ray (1994) - see also Duclos, Esteban \& Ray (2004) - and Wolfson (1994), we have now a set of rigorously founded measures of polarization. Wang \& Tsui (2000), Reynal-Querol (2001, 2002) and Zhang \& Kanbur (2001) have developed and tested alternative measures of polarization. ${ }^{1}$ Some of them are used in the articles that are part of this special issue. Loosely speaking, in any given distribution of characteristics, we mean by polarization the extent to which the population is clustered around a small number of distant poles. This notion of polarization is particularly relevant to the analysis of conflict, because it stands for the idea that the tensions within a society of individuals or states result from two simultaneous decisions: identification with other subjects within the own group of reference and distancing oneself from one or several other competing groups. Consequently, following Esteban \& Ray (1994), any measure of polarization has to possess the following basic traits:

1. Polarization is a systemic attribute and mainly considers groups as the crucial actors. Isolated individuals should therefore have little weight in the calculation of social polarization.

2. The level of polarization increases with the degree of homogeneity within each group.

3. There must be a high degree of heterogeneity across groups.

4. The number of significantly sized groups must be relatively small.

All the polarization measures cited above do satisfy these four properties, while alternative

${ }^{1}$ An alternative and - considerably cruder - specification of polarization which also does not include a proxy for intragroup homogeneity is the concept of dominance that Collier (2001) introduced. It qualifies societies as 'dominated' if the largest group contains between $45 \%$ and $90 \%$ of the overall population. See also Ellingsen (2000), who defines dominant groups similarly. 
measures are not based on all of these conditions.

It is plain, in this respect, that the notion of polarization is nearly orthogonal to the frequently used notion of 'fractionalization' or 'power concentration' - which is the complement of the well-known HirschmanHerfindahl measure of concentration (cf. Hirschman, 1964). The measure of fractionalization can be understood as the probability that two randomly chosen individuals happen to belong to different groups.

The measures of fractionalization and polarization differ on two major counts. In the first place, while a larger number of groups increases fractionalization, it decreases polarization - with a maximum level of polarization for two equally sized groups. Second, most measures of polarization - but not Reynal-Querol's (2001, 2002) indicator consider intergroup distances to be crucial, while fractionalization measures do not include this information.

As polarization and fractionalization try to capture different aspects of the distribution of the population over a set of characteristics, we should expect them to influence the risk and magnitude of violent conflict differently. The key point that we wish to examine in this special issue is whether fragmented or bipolar distributions are more likely to generate social conflict. This question can be addressed theoretically and empirically.

\section{Theoretical and Empirical Work on Polarization and Conflict}

The hypothesis that conflict is related to social, economic and political polarization has preoccupied political science, economics and the other social sciences for decades. In economics, the literature on this topic grows out of the literature on rent-seeking games. Political scientists have, by contrast, looked at polarization initially in the context of theories that proposed a link between the global power distribution and militarized forms of conflict. We discuss the theoretical contributions that have been made so far before we move to a presentation of the key empirical results.

\section{Theoretical Work}

The most general model on the nexus between the distribution of the population over groups with opposing interests and conflict is due to Esteban \& Ray (1999). In the tradition of the rent-seeking literature, they conceive of conflict as the losses competing groups impose on each other to reach their preferred option. A society of individuals or states reaches the maximal amount of conflict, under the fairly general assumption of this model, when the population is distributed into two equally sized groups. In contrast, a highly fractionalized society would be associated with a low level of equilibrium conflict. Hence, bimodal power distributions should indeed be associated with the highest levels of military spending. Whether bipolarity is also linked to the highest risk of violent forms of conflict is an open theoretical and empirical question.

Quite independently and for a long time, the international relations literature has witnessed a controversy over the stabilizing or destabilizing effects of 'polarity'. Balance-ofpower theorists have argued for centuries that even distributions of power across the major powers are pacifying the international system (Morgenthau, 1973). In their perspective, power parity provides a balance of threat. Some realists even contend that one specific distribution of resources - bipolarity stabilizes the international system. Waltz (1964, 1979), for instance, maintains that bipolarity is the ultimate force for peace, because decisionmakers are better able to judge the preferences of a potential foe. Deutsch \& Singer (1964), by contrast, advanced the position that a 'multipolar' system is to be associated with more uncertainty and that it is consequently more stable 
than a bipolar one. The empirical literature that deals with this controversy between the proponents of bipolarity and multipolarity has, however, not come to clear results. As Geller \& Singer (1998:113) write, 'confusion rather than clarity has characterized the debate'.

The crisis bargaining literature has, however, illuminated the discussion between balance of power and parity theorists to a considerable extent. The pathbreaking synthesis of this controversy by Powell (1999) shows, through the distinction between the disparity of power and benefits, that both theories have to be modified. In Powell's bilateral bargaining model, the risk of conflict is minimal in two instances: first, if there is a preponderance of power and benefits favouring one major power and, second, in the event of parity on both dimensions. One important distinction that has to be made is between how costly a conflict will be if it erupts at all, and how likely it is that one party or country decides to violate the existing agreements and trigger a costly conflict in the first place. The costlier a conflict is, the more unlikely that any party will decide to break the existing status quo, and the higher the expected gains. Hence, bipolar situations, as they create a huge cost in the case of open conflict, easily sustain status quo agreements. Notice, however, that this argument assumes that all the parties have common information concerning the expected costs in case of conflict. With full and common information, there appears to be no reason why the parties with opposing conflict could not find an individually rational peaceful agreement. This means, on the other hand, that convincing explanations have to attribute conflict to strategic uncertainty, at least to some extent. It is, therefore, not surprising that Powell (1999) and others have put asymmetric information at the centre stage of their theoretical synthesis.

Another traditional and competing hypothesis in the international relations literature relates peace to the existence of one powerful state. The power preponderance school of thought believes, accordingly, in the pacifying effects of unipolarity and, thus, the possibility to deter leadership challenges early on (Organski, 1968). In a temporal perspective, the important question is whether the risk of conflict is greatest before or after parity levels have been reached. Kadera's (2001:105) computational models of dyadic conflict address this issue and support the view that 'a pair of rival nations is most conflictual immediately following a power transition'. How these results translate into a multilateral setting where states can also ally to deter threats remains, however, unclear.

From a universalist perspective, the mechanisms that drive a system of states into war should be identical to those that increase the risk of violence among competing groups. Unfortunately, there is a substantial gap between theoretical and empirical progress in the study of civil war. Moreover, sophisticated models on interstate war that have been developed as part of the literature on deterrence and crisis bargaining have not been applied to the domain of intrastate interactions. In his model of civil war duration, Fearon (2004) addresses the issue of power distribution only in passing and refers to the burgeoning literature on war as a bargaining process. We believe, however, that much more theoretical work needs to be developed seeking for convincing explanations for the usage of armed force across different political and social systems. Future theories have to highlight, in particular, the varying commitment devices and mobilization strategies on which political actors can rely.

\section{Empirical Studies}

The empirical literature on rent-seeking contests is sparse and mainly experimental (e.g. Potters, de Vries \& van Winden, 1998). If one disregards the early studies on groupthink and the polarization of beliefs in 
decisionmaking committees, no widely cited experiment on the relationship between polarity and the usage of violence exists. Quasi-experimental evidence that links some operational definition of polarization to armed conflict has consequently been mainly gathered in political science.

Reflecting the development within the field of quantitative international relations, the first studies tested the relationship between the allocation of resources across major powers and the occurrence of war in the Westphalian state system. As indicated, no clear relationship could be found between international war and 'polarity' or 'polarization'. The ambiguity of the extant empirical work might be largely a consequence of the crude way in which the key concept of polarity has often been operationalized. Simply counting the number of poles fails to include information on the heterogeneity of the contending alliances.

The variable that most closely resembles polarization as understood by Duclos, Esteban \& Ray (2004) is 'capability concentration', introduced to the literature by Singer, Bremer \& Stuckey (1972) and Ray \& Singer (1973). They find that the concentration of power within the state system only marginally affects the likelihood of conflict. Replications of the Singer, Bremer \& Stuckey (1972) study have largely come up with further qualifications or non-significant results (e.g. Mansfield, 1994). To gauge the impact of alliance cohesion on the likelihood of war, Bueno de Mesquita $(1975,1978)$ has introduced the measure of tightness of the alliance system. This variable stands for the similarity of alliance portfolio choices and is measured through the calculation of the $\mathrm{Tau}_{\mathrm{b}}$ scores to identify how nation-states cluster into blocs or poles. His empirical applications of this measure of alliance tightness remain, however, insignificant (Bueno de Mesquita, 1978; Bueno de Mesquita \& Lalman, 1988). ${ }^{2}$ Wayman's (1984) statistical study addresses the ambiguity of the concept of bipolarity in a similar way to Bueno de Mesquita's work. He shows particularly that bipolar power structures reduce the magnitude of war, while bipolar alliance structures increase the risk of militarized conflict.

In the study of civil war, Ellingsen (2000) was the first to regress a variety of diversity indicators on domestic civil unrest. She showed that countries in which the population share of the dominant group is less than $80 \%$ experience civil wars more frequently than more homogeneous countries. She also established that the relationship between the number of groups and conflict is curvilinear, with highly diverse and highly homogeneous states facing a lower risk of conflict than countries with a few strong groups. This regularity could have served as a warning that regressing fractionalization on the risk of war might lead to inconclusive results. Subsequent studies, nevertheless, often referred to fragmentation as a proxy for the cleavage structure within a country. Although the study by Hegre et al. (2001) on the civil democratic peace has come up with a positive effect of this indicator on the risk of conflict, subsequent examinations have qualified this result. Drawing on empirical studies on the impact of polarization on economic growth, Reynal-Querol (2002) pointed out the importance of religious polarization. Collier \& Hoeffler (2004) showed that the contested dominance of one large group, rather than fractionalization, increases the probability of civil war. In their view, this is due to the fact that fractionalization reduces the possibility of marginal groups organizing themselves effectively. In the meantime, new measures have emerged that allow researchers to develop much better measures of ethnic fractionalization (Alesina et al., 2003; Fearon, 2003).

\footnotetext{
2 Signorino \& Ritter (1999) criticize this measure for not adequately measuring the similarity of alliance portfolios and introduce a more general spatial measure of foreign policy similarity.
} 


\section{Special Issue Articles}

The articles published in this issue can be viewed as providing conceptual and empirical answers to three sets of questions: (1) What is the relationship between polarization and conflict under alternative institutions, and what form of inequality and diversity affect the risk of violence? (2) How do groups form and how are intergroup coalitions built and sustained in a polarized society? (3) What is the interrelationship between international conflict and polarization.

Østby (2008) compares measures of inequality and polarization and takes issue with the finding of some quantitative studies that inequality does not increase the risk of internal armed conflict. She argues that these studies fail to account for horizontal inequalities and thus the concurrence of systematic inequalities with ethnic cleavages. She uses data from the Demographic and Health Surveys (DHS) for 36 developing countries for her empirical tests and shows that horizontal social inequality is positively related to conflict outbreak. She also finds that the related concept of polarization increases the risk of violence.

Comparative politics has dealt for a long time with the question of the extent to which political institutions are epiphenomena of the cleavage structure. While political sociologists have largely advanced this claim, formal theorists have also argued that institutional arrangements influence the social cohesion within a country. Esteban \& Ray (2008) and Schneider \& Wiesehomeier (2008) both bring the institutional environment into consideration: the impact of polarization has to depend on the ability of the institutional system to satisfy competing claims.

Esteban \& Ray (2008) show, in a theoretical article, that the institutional setting influences the interactions among competing groups and influences the attractiveness of resorting to war in comparison to peace. In their model, conflict breaks out whenever a group prefers the (costly) outcome of conflict over the payoff that it could gain under peace. The model demonstrates that highly polarized situations may not yield open conflict because of the high costs incurred. The prediction of their model is that (small scale) conflict is most likely in societies with high fractionalization and low polarization. Furthermore, when comparing across systems, the closer the peace payoff is to the conflict payoff, the more unlikely will it be that conflict breaks out.

The article by Schneider \& Wiesehomeier (2008) examines the extent to which institutions can mediate the conflicts within divided societies from an empirical point of view. Their analysis confirms that one needs to take the institutional context into account if one analyses the impact of different forms of diversity on the risk of civil unrest. In line with Esteban \& Ray (2008), they highlight that, in democracies, fractionalization has a positive impact on the risk of civil war, and the risk of violence is higher when the democratic institutions are majoritarian. The latter finding supports the vision of Dutch-American political scientist Lijphart $(1968,1999)$ who has advocated for generations the peaceful effects of power-sharing mechanisms in divided societies.

The second set of issues focuses on how social polarization may affect the creation of social cleavages and the formation of groups to achieve common interests. The article by Buskens, Corten \& Weesie (2008) uses a dynamic network-formation model to show the conditions under which segregation occurs and polarized communities emerge. Such patterns are likely because cooperation can also be costly in pure coordination games. The degree to which polarization on a behavioural trait occurs depends on patterns of social ties, but this social structure itself is also influenced by behavioural choices. Accordingly with their results, dense networks lead to more homogeneous behaviour, while more segmented and segregated networks 
have the opposite effect. In this sense, social polarization is an absorbing state.

Political polarization and/or policy fractionalization may negatively affect the potential to enact policy reforms. To explore the relative explanatory value of this hypothesis, Torenvlied \& Haarhuis (2008) contrast the theory of polarization with veto-player theory. Building on Cox \& McCubbins (2001), they distinguish between decisiveness and resoluteness of political systems in enacting reform measures. Using a dataset of 32 case studies of anti-corruption reform issues in seven sub-Saharan African countries, they find empirical support for the veto-player theory. They also find that policy fractionalization has significant and negative effects on the level of reform.

The processes of social polarization are also subject to external influences. Lijphart (1968) made the point that external threats are an incentive to maintain cooperation across social cleavages. Indridason (2008) tests this conjecture and examines whether terrorist activity affects government stability. He finds that coalitions formed under terrorist threat are less likely to be highly polarized and will have a broader support. This suggests that the analysis of domestic conflict and social polarization needs to be placed in a wider, international perspective.

Indeed, this special issue also contributes to the discussion on the nexus between polarization and conflict in the international scene. Hegre (2008) addresses the question of whether world polarization is a good predictor of the occurrence and the intensity of interstate conflict. He uses two forms of polarization the world-wide distribution of income and the distribution of political systems - to analyze the claims made by several authors that polarization affects the conflict propensity at the system level of analysis. His analysis complements the traditional studies that have exclusively looked at the global distribution of capabilities to bolster their theoretical claims.
As it is with most system-level analyses, the results of this applications are, however, rather inconclusive. This calls for a reconsideration of the way in which we test system-level explanations and additional tests that take power and preference configurations into account.

As Hegre (2008) himself points out, one of the open leads of his empirical study is that interstate conflict is very unlikely between geographically distant nations. Indeed, vicinity is a factor that should definitely be taken into account to explain international conflict. This is the line taken by Forsberg (2008), who studies the role of polarization in the international contagion of ethnic conflicts. Her main contribution is to empirically substantiate the view that the regional perspective is essential in explaining the occurrence of ethnic conflict. She finds empirical evidence that the strength of ethnic groups in a particular country spills over to the kin groups in neighbouring countries. Furthermore, polarized countries, besides being more prone to ethnic conflict, also seem to be more exposed to contagion processes from their neighbours.

\section{Conclusion}

One of the main and increasingly accepted conjectures in the social sciences is the hypothesis that increasing polarization increases the risk of conflict, including armed violence. Although balance-of-power theorists are still influential, the growing available evidence shows that power parity is rather associated with an increased risk of conflict. Similarly, Esteban \& Ray (1999) demonstrate, from a political economy perspective, that bipolarization of income or preferences maximizes the costs that competing groups incur onto each other. The contributors to this volume examine these related claims systematically and identify some of the conditions under which growing divisions within a society - of individuals or of nation-states - are indeed linked to the use of militarized force. 
Extensions of this work will examine how polarization induces other anomalies, such as the breakdown of social and political order, political instability, strikes and other nonviolent ways in which one group tries to hurt a competing group. We have strong reasons to believe that polarization also reduces the willingness of humans to contribute to common causes, reducing the provision of public goods and hampering the economic prospects of developing countries.

At the moment, most studies use fractionalization to gauge the impact of societal divisions on various public policy outcomes. We believe, however, that, rather than heterogeneity per se, it is polarization between competing groups that is the driving force behind the correlations found in this literature so far.

Practically and academically, the articles assembled in this special issue will help to sort out what dysfunctional effects social and political divisions have, and whether some forms of group competition are beneficial to a society. In so doing, polarization researchers will help to clarify the causes and consequences of related concepts, such as inequality, fractionalization and concentration. The research summarized in this special issue will alert us to the wider dangers of political polarization. Although most commentators believe that increased divisions within a society endanger democracy and undermine social progress, we have only just started to understand these processes and their impact upon society.

\section{References}

Alesina, Alberto; Arnaud Devleeschauwer, William Easterly, Sergio Kurlat \& Romain Wacziarg, 2003. 'Fractionalization', Journal of Economic Growth 8(2): 155-194.

Bracher, Karl Dietrich, 1955. Die Auflösung der Weimarer Republik. Eine Studie zum Problem des Machtverfalls in der Demokratie [The Dissolution of the Weimar Republic. A Survey on the Problem of Power Decline in Democracy]. Stuttgart, Düsseldorf: Ring Verlag.
Brooks, David, 2004. 'Age of Political Segregation', New York Times, 29 June.

Bueno de Mesquita, Bruce, 1975. 'Measuring Systemic Polarity', Journal of Conflict Resolution 19(2): 187-216.

Bueno de Mesquita, Bruce, 1978. 'Systemic Polarization and the Occurrence and Duration of War', Journal of Conflict Resolution 22(2): 241-267.

Bueno de Mesquita, Bruce \& David Lalman, 1988. 'Empirical Support for Systemic and Dyadic Explanations of International Conflict', World Politics 41(1): 1-20.

Buskens, Vincent, Rense Corten \& Jeroen Weesie 2008. 'Consent or Conflict: Coevolution of Coordination and Networks', Journal of Peace Research 45(2): 000-000.

Collier, Paul, 2001. 'Implications of Ethnic Diversity', Economic Policy 16(32): 129-66.

Collier, Paul \& Anke Hoeffler, 2004. 'Greed and Grievance in Civil War', Oxford Economic Papers 56(4): 563-595.

Cox, Gary W. \& Matthew D. McCubbins, 2001. 'The Institutional Determinants of Economic Policy Outcomes', in Steve Haggard \& M. D. McCubbins, eds, Presidents, Parliaments, and Policy. Cambridge, MA: Cambridge University Press (21-63).

De Tocqueville, Alexis, 1857. L'ancien régime et la Révolution [The Ancien Régime and the Revolution], 3rd edn. Paris: Lévy.

Deutsch, Karl Wolfgang \& J. David Singer, 1964. 'Multipolar Power Systems and International Stability', World Politics 16(3): 390-406.

Duclos, Jean Yves; Joan Esteban \& Debraj Ray, 2004. 'Polarization: Concepts, Measurement, Estimation', Econometrica 72(6): 1737-1772.

Ellingsen, Tanja, 2000. 'Colorful Community or Ethnic Witches' Brew? Multiethnicity and Domestic Conflict During and After the Cold War', Journal of Conflict Resolution 44(2): 228-249.

Esteban, Joan \& Debraj Ray, 1994. 'On the Measurement of Polarization', Econometrica 62(4): 819-851.

Esteban, Joan \& Debraj Ray, 1999. 'Conflict and Distribution', Journal of Economic Theory 87(2): 379-415.

Esteban, Joan \& Debraj Ray, 2008. 'Polarization, Fractionalization, and Conflict', Journal of Peace Research 45(2): 000-000. 
Fearon, James D., 2003. 'Ethnic and Cultural Diversity by Country', Journal of Economic Growth 8(2): 195-222.

Fearon, James D., 2004. 'Why Do Some Civil Wars Last So Much Longer Than Others?', Journal of Peace Research 41(3): 275-301.

Forsberg, Erika, 2008. 'Polarization and Ethnic Conflict in a Widened Strategic Setting', Journal of Peace Research 45(2): 000-000.

Frye, Timothy, 2002. 'The Perils of Polarization: Economic Performance in the Postcommunist World', World Politics 54(3): 308-337.

Geller, Daniel S. \& J. David Singer, 1998. Nations at War: A Scientific Study of International Conflict. Cambridge, MA: Cambridge University Press.

Hegre, Håvard, 2008. 'Polarization and Interstate Conflict', Journal of Peace Research 45(2): 000-000.

Hegre, Håvard; Tanja Ellingsen, Scott Gates \& Nils Petter Gleditsch, 2001. 'Towards a Democratic Civil Peace? Democracy, Political Change, and Civil War, 1816-1992', American Political Science Review 95(1): 33-48.

Hirschman, Albert O., 1964. 'The Paternity of an Index', American Economic Review 54(5): 761-762.

Indridason, Indridi H., 2008. 'Does Terrorism Influence Domestic Politics? Coalition Formation and Terrorist Incidents', Journal of Peace Research 45(2): 000-000.

Kadera, Kelly M., 2001. The Power-Conflict Story: A Dynamic Model of Interstate Rivalry. Ann Arbor, MI: University of Michigan Press.

Keefer, Philip \& Stephen Knack, 2002. 'Polarization, Politics and Property Rights: Links Between Inequality and Growth', Public Choice 111(1-2): 127-154.

Layman, Geoffrey C. \& Thomas M. Carsey, 2002. 'Party Polarization and "Conflict Extension" in the American Electorate', American Journal of Political Science 46(4): 786-802.

Lichbach, Mark Irving, 1989. 'An Evaluation of "Does Economic Inequality Breed Political Conflict?" Studies', World Politics 41(4): 431-470.

Lijphart, Arend, 1968. The Politics of Accommodation: Pluralism and Democracy in the Netherlands. Berkeley, CA: University of California Press.
Lijphart, Arend, 1999. Patterns of Democracy: Government Forms and Performance in Thirty-Six Countries. New Haven, CT: Yale University.

Linz, Juan J., 1978. 'Crisis, Breakdown, and Reequilibration', in Juan J. Linz \& Alfred Stepan, eds, The Breakdown of Democratic Regimes. Baltimore, MD \& London: Johns Hopkins University Press (3-124).

Lukov, Yaroslav, 2004. 'Rival Camps Braced for Ukraine Polls', BBC News World Edition, 24 December 2004 (http://news.bbc.co.uk/2/hi/ europe/4123907.stm, last consulted 5 July 2005).

MacAskill, Ewan, 2003. 'Jihad Has Worked - The World Is Now Split In Two', The Guardian, 8 December.

Mansfield, Edward D., 1994. Power, Trade, and War. Princeton: Princeton University Press.

Marx, Karl, 1931 [1867]. Das Kapital: Kritik der politischen Ökonomie [Capital: A Review of Political Economy]. Berlin: Laub.

Montalvo, Jose G. \& Marta Reynal-Querol, 2005. 'Ethnic Polarization, Potential Conflict and Civil Wars', American Economic Review 95(3): 796-816.

Morgenthau, Hans, 1973. Politics Among Nations, 5 th edn. New York: Knopf.

Organski, Abramo Fimo Kenneth, 1968. World Politics, 2nd edn. New York: Knopf.

Østby, Gudrun, 2008. 'Polarization, Horizontal Inequalities, and Violent Civil Conflict', Journal of Peace Research 45(2): 000-000.

Potters, Jan; Casper G. de Vries, \& Frans van Winden, 1998. 'An Experimental Examination of Rational Rent-Seeking', European Journal of Political Economy 14(4): 783-800.

Powell, Robert, 1999. In the Shadow of Power: States and Strategies in International Politics. Princeton, NJ: Princeton University Press.

Ray, James \& Singer, J. David, 1973. 'Measuring the Concentration of Power in the International System', Sociological Methods and Research 1(4): 403-437.

Reynal-Querol, Marta, 2001. Ethnic and Religious Conflict, Political Systems and Growth. PhD thesis, London School of Economics.

Reynal-Querol, Marta, 2002. 'Ethnicity, Political Systems, and Civil Wars', Journal of Conflict Resolution 46(1): 29-54. 
Rosenberg, William G. \& Diane P. Koenker, 1987. 'The Limits of Formal Protest: Worker Activism and Social Polarization in Petrograd and Moscow, March to October, 1917', American Historical Review 92(2): 296-326.

Schneider, Gerald \& Nina Wiesehomeier, 2008. 'Rules that Matter: Political Institutions and the Diversity-Conflict Nexus', Journal of Peace Research 45(2): 000-000.

Signorino, Curtis. S. \& Jeffrey M. Ritter, 1999. 'Tau-b or Not Tau-b: Measuring the Similarity of Foreign Policy Positions', International Studies Quarterly 43(1): 115-144.

Singer, J. David, Stuart A. Bremer \& John Stuckey, 1972. 'Capability Distribution, Uncertainty, and Major Power War, 1820-1965', in Bruce M. Russett, ed., Peace, War, and Numbers. New York: Free Press (19-48).

Speth, James G., 1996. Speech on the 1996 Human Development Report, National Press Club, Washington DC, 16 July (ftp://lists. inet.co.th/pub/sea-aids/plun/plun37.txt).

Times 2007. Pakistan's Catch-22, 6 July 2007 (available at http://www.timesonline.co.uk/tol/ comment/leading_article/article2033872.ece, last consulted 2 August 2007).

Torenvlied, René \& Carolien M. Klein Haarhuis, 2008. 'Polarization and Policy Reform: AntiCorruption Policy-Making in Sub-Saharan Africa', Journal of Peace Research 45(2): 000-000.

Waltz, Kenneth N., 1964. 'The Stability of a Bipolar World', Daedalus 93(3): 881-909.

Waltz, Kenneth N., 1979. Theory of International Politics. Reading, MA: Addison-Wesley.
Wang, You Qiang \& Kai Yuen Tsui, 2000. 'Polarization Orderings and New Classes of Polarization Indices', Journal of Public Economic Theory 2(3): 349-363.

Wayman, Frank Whelon, 1984. 'Bipolarity and War: The Role of Capability Concentration and Alliance Patterns Among Major Powers, 1816-1965', Journal of Peace Research 21(1): 61-78.

Winkler, Heinrich August, 1994. Weimar 1918-1933: die Geschichte der ersten deutschen Demokratie [Weimar 1918-1933: History of the First German Democracy]. Frankfurt: Büchergilde Gutenberg.

Wolfson, Michael C., 1994. 'When Inequalities Diverge', American Economic Review Papers and Proceedings 84(2): 353-358.

Woo, Jaejoon, 2005. 'Social Polarization, Fiscal Instability and Growth', European Economic Review 49(6): 1451-1477.

Zhang, Xiaobo \& Ravi Kanbur, 2001. 'What Difference Do Polarization Measures Make? An Application to China', Journal of Development Studies 37(3): 85-98.

JOAN ESTEBAN, b. 1945, Dr. phil Oxon (1988); Research Professor, Institut d'Anàlisi Econòmica, Barcelona; President, Society for the Study of Economic Inequality (2007-09).

GERALD SCHNEIDER, b. 1962, Dr. phil., University of Zürich (1991); International Relations Chair, University of Konstanz (1997-); Executive Editor, European Union Politics. 